\title{
Mutu Produk Madu yang Dijual di Surabaya
}

Eka Aprillia Suhartini, Juniar Moechtar, Asri Darmawati*

Fakultas Farmasi, Universitas Airlangga, Surabaya

*Corresponding author: asri-d@ff.unair.ac.id

\begin{abstract}
Background: Honey is a natural viscous liquid with sweet taste produced by honey bees from the nectar flowers or other parts of plants. The marketed honey products must have a registration number from BPOM RI and fulfill the requirement parameters of quality as stated in the Indonesian National Standard (SNI) of 01-35452013. The honey registration numbers are beginning with codes of ML, MD, TR and P-IRT. The different codes indicate the manufacturer categories. Objective: The aim of this study was to know whether the quality of honey product of the different producer category fulfill the SNI 01-3545-2013 requirement. Methods: In this research, the four honey samples were compared their quality based on SNI quality parameters. Each sample products represent one code registration number category. The samples were randomly selected from several names of honey products with the same code registration category. The 13 SNI parameters included organoleptic, moisture content, ash content, water-insoluble solids content, acidity, diastase enzyme activity, hydroxymethylfurfural $(\mathrm{HMF})$ concentration, metal contaminants $(\mathrm{Pb}, \mathrm{Cd}, \mathrm{Hg}, \mathrm{As})$, limit of chloramphenicol concentration, microbial contaminant, and concentration of reducing sugars and sucrose. Results: This study resume were as follows the sample with MD and P-IRT codes fulfilled the test requirements except the HMF concentration that was out of the requirement value. The sample with $M L$ code fulfilled all test requirements except value of the $H M F$ and ash content. The sample of TR code fulfilled the requirements except the water content. Conclusion: All honey samples were fulfilled 12 of 13 quality parameter according to SNI 01-3545-2013.
\end{abstract}

Keywords: honey, honey products, Surabaya

\begin{abstract}
Abstrak
Pendahuluan: Madu adalah cairan alami dengan konsistensi kental dan rasa manis yang dikumpulkan oleh lebah madu dari sari bunga atau bagian lain tumbuhan. Produk madu yang dipasarkan harus memiliki nomor registrasi yang dikeluarkan oleh Badan Pengawas Obat dan Makanan Republik Indonesia (BPOM RI) dan memenuhi persyaratan mutu yang ditetapkan oleh Standar Nasional Indonesia (SNI) 01-3545-2013. Nomor registrasi produk madu diawali dengan kode ML, MD, TR dan P-IRT. Perbedaan kode awal pada nomor registrasi menunjukkan katagori produsen pengolah produk madu. Tujuan: Tujuan penelitian ini adalah mengetahui mutu produk madu yang diregistrasi dengan katagori berbeda mengacu persyaratan SNI 01-3545-2013. Metode: Dalam penelitian ini mutu 4 sampel produk madu dibandingkan dengan acuan parameter SNI untuk madu. Setiap sampel produk madu mewakili satu kode awal nomor registrasi. Nama sampel tersebut dipilih secara acak dari beberapa nama produk madu dengan kode awal nomor registrasi yang sama. Parameter SNI yang diuji meliputi: organoleptis, kadar air, kadar abu, kandungan padatan tidak larut air, keasaman, kadar -5-hydroxymethylfurfuraldehyde (HMF), aktivitas enzim diastase, cemaran logam ( $\mathrm{Pb}, \mathrm{Cd}, \mathrm{Hg}, \mathrm{As}$ ), kadar batas kloramfenikol, cemaran mikrobiologi, kadar gula pereduksi dan sukrosa. Hasil: Resume hasil penelitian ini adalah: sampel dengan kode awal MD dan P-IRT memenuhi persyaratan parameter SNI, kecuali kadar HMF melebihi batas yang ditetapkan. Sampel dengan kode awal ML memenuhi persyaratan SNI kecuali kadar HMF dam kadar abu. Sampel dengan kode awal TR memenuhi persyaratan SNI kecuali kadar air. Kesimpulan: Semua sampel madu memenuhi 12 dari 13 persyaratan parameter mutu SNI-01-3545-2013.
\end{abstract}

Kata kunci: madu, produk madu, Surabaya 


\section{PENDAHULUAN}

Madu adalah cairan alami, umumnya mempunyai rasa manis, diproduksi oleh lebah madu dari sari bunga tanaman atau bagian lain dari tanaman (BSN, 2013). Madu merupakan makanan yang baik untuk bayi maupun orang dewasa (White Jr dkk., 1980).

Kode awal nomor registrasi produk madu adalah ML, MD, TR, P-IRT. Kode awal nomor registrasi tersebut menunjukkan status/kelas produsen madu yang bersangkutan. Kode P-IRT menunjukkan produk tersebut diproduksi oleh Industri Rumah Tangga (IRT) dan telah memenuhi persyaratan yang ditetapkan Bupati/ Walikota untuk diedarkan di wilayah kerjanya (BPOM RI, 2012). Kode MD dan ML diberikan kepada produk makanan dan minuman dan telah memenuhi persyaratan yang ditetapkan BPOM RI untuk diedarkan di wilayah Indonesia. Kode TR adalah nomor izin edar untuk obat tradisional produksi dalam negeri (Depkes RI, 2012).

Berdasarkan SNI 01-3545-2013 (BSN, 2013) terdapat 13 parameter mutu madu yaitu organoleptik, kadar air, kadar abu, kandungan padatan tidak larut air, derajat keasaman, aktivitas enzim diastase, kadar hidroksimetil-furfural (HMF), cemaran logam $(\mathrm{Pb}, \mathrm{Cd}$, $\mathrm{Hg}$, As), batas kadar kloramfenikol, cemaran mikroba, kadar gula pereduksi dan kadar sukrosa.

Perbedaan mutu madu dapat disebabkan oleh perbedaan cara pengolahan atau metode produksi di masing-masing industri. Selain itu, variasi komposisi kimia madu juga tergantung pada sumber tanaman dan musim pemanenan (Anonim, 1998).

Madu yang matang memiliki kadar air rendah dan kadar fruktosa tinggi (Sihombing, 1997). Kenaikan kadar air dalam madu selama penyimpanan akan memacu proses fermentasi (White, 1992). Keasaman yang tinggi dapat menjadi indikasi fermentasi gula menjadi asam organik (Gomes dkk., 2010).

Hasil dekomposisi fruktosa dalam kondisi asam adalah HMF. Senyawa ini tidak ditemui dalam madu segar, tetapi HMF meningkat selama proses pengolahan dan penyimpanan (Zappala dkk., 2005). Proses ini terjadi secara alami, namun tingginya kadar HMF dapat mengindikasikan penyimpanan yang tidak memadai, pemanasan yang tinggi atau adanya pemalsuan dengan gula aditif (Keppy \& Allen, 2009). Belum ada penelitian yang melaporkan adanya efek karsinogenik dari HMF.

Enzim diastase adalah enzim yang mengubah polisakarida menjadi monosakarida. Sumber enzim diastase dalam madu adalah lebah madu sendiri, meski ada juga yang menduga nektar sebagai sumbernya
(Suranto, 2004). Enzim diastase digunakan sebagai penanda untuk mengevaluasi kesegaran atau kerusakan madu. Pada pemalsuan madu yang dicampur dengan sukrosa atau High Fructose Corn Syrup (HFCS), terjadi pengurangan jumlah enzim diastase.

Tujuan penelitian ini adalah untuk mengetahui apakah mutu produk madu yang dihasilkan oleh produsen yang berbeda kategori tersebut memenuhi persyaratan yang ditetapkan (BSN, 2013).

\section{BAHAN DAN METODE \\ Bahan}

Natrium hidroksida, kalium ferosianida, seng asetat, natrium bisulfit, iodum, kalium iodida, amilum soluble, natrium klorida, fenolftalein, natrium asetat, asam asetat glasial, asam oksalat, natrium tio sulfat, asam klorida, asam sulfat, asam nitrat, kalium ferosianida. Larutan standar raksa (II) nitrat, natrium arsenat, timbal(II) nitrat dan kadmium nitrat. Semua bahan tersebut, kecuali dinyatakan lain, berderajat kemurnian pro analisis (dari E.Merck).

Alat

Furnace (Thermolyne 48010-33), ultrasonic (Branson 3510), waterbath (Thermostart HH-6), timbangan analitik (O'Hauss), hotplate (IKA C-MAG HS 4), oven (venticell MMM Medcenter), Maxi mix type 37600 mixer, furnace (Barnstead thermolyne), lempeng KLT silika gel $60 \mathrm{GF}_{254}$ (Merck), Incubator (Memmert), Colony counter Model 570, Laminar Air Flow Model AVC-4D1, Lovibond ThermostatControlled Incubator dan alat-alat gelas lain.

Spektrofotometer UV-Vis (Perkin Elmer lambda EZ201-1), pH meter (WTW 720), Atomic Absorption Spectrophotometer (Contra AA 700, Analytic Jena), densitometer (Camag TLC Scanner 4), lampu UV CAMAG.

\section{Metode}

\section{Lokasi penelitian}

Pengujian parameter mutu dalam penelitian ini dilakukan di dua laboratorium sebagai berikut:

1. Laboratorium analisis Farmasi Fakultas Farmasi Universitas Airlangga untuk uji organoleptis, kadar air, kadar abu, kandungan padatan tidak larut air, derajat keasaman, aktivitas enzim diastase dan kadar HMF

2. Laboratorium Unit Layanan Pengujian (ULP) Fakultas Farmasi Universitas Airlangga untuk uji cemaran logam ( $\mathrm{Pb}, \mathrm{Cd}, \mathrm{Hg}$, As), batas kadar kloramfenikol, cemaran mikroba, kadar gula pereduksi dan sukrosa 


\section{Sampling}

Dilakukan survei di toko swalayan yang berada di 4 wilayah Surabaya yang menjual produk madu untuk dicatat nama dan nomor registrasi semua produk madu yang dijual. Nama produk madu dikelompokan berdasarkan kategori nomor registrasi. Selanjutnya setiap kategori nomor registrasi dipilih secara random satu nomor registrasi untuk mewakili golongan tersebut. Sampel penelitian adalah 4 produk madu, masing-masing diambil dari toko swalayan berbeda, yaitu ML.237608001190, MD.137611002072, TR.053650821 dan P-IRT.109357813230.

\section{Persiapan sampel}

Mengacu pada BSN (2013), analisis dilakukan langsung terhadap sampel tanpa perlakuan lain kecuali penyaringan, pengadukan dan pengocokan. Jika mengandung bagian-bagian yang menggumpal maka sampel dihangatkan dalam wadah tertutup di atas penangas air $60-65^{\circ} \mathrm{C}$ selama 30 menit. Selama pemanasan, sampel digoyang/diaduk sewaktu-waktu dan didinginkan setelah mencair seluruhnya.

\section{Uji kadar air}

Mengacu pada BSN (1992), ditimbang teliti 2,0 g sampel dalam krus porselin yang sudah diketahui berat konstannya. Sampel dalam krus dipanaskan dalam oven suhu $105^{\circ} \mathrm{C}$ selama 4 jam. Setelah didinginkan dalam eksikator selama 15 menit, krus ditimbang. Pengeringan dilanjutkan dan ditimbang lagi, pada jarak 1 jam, sampai perbedaan antara dua penimbangan berturut-turut tidak lebih dari $0,25 \%$.

\section{Uji kadar abu}

Mengacu pada BSN (1992), ditimbang teliti 2,5 g sampel madu dalam krus porselin yang sudah diketahui berat konstannya. Kemudian sampel dalam krus diabukan dalam furnace $550^{\circ} \mathrm{C}$ selama 4 jam. Setelah krus didinginkan dalam eksikator selama 15 menit, kemudian ditimbang. Pengeringan dilanjutkan dan ditimbang lagi, pada jarak 1 jam, sampai perbedaan antara dua penimbangan berturut-turut tidak lebih dari $0,25 \%$.

\section{Uji padatan tidak larut air}

Mengacu pada BSN (1992), Ditimbang teliti 20,0 g sampel dimasukkan ke dalam beaker glass $250 \mathrm{~mL}$, ditambah $200 \mathrm{~mL}$ air suling panas, aduk hingga larut. Kemudian dalam keadaan panas, cairan dituangkan ke dalam kertas saring yang sudah diketahui berat konstannya dengan dipanaskan dalam oven suhu $100^{\circ} \mathrm{C}$ selama 2 jam. Kemudian kertas saring dimasukkan ke dalam krus porselen yang sudah diketahui berat konstannya. Krus berisi kertas saring dipanaskan dalam oven suhu $105^{\circ} \mathrm{C}$ selama 2 jam, setelah didinginkan dalam eksikator, krus ditimbang sampai berat konstan.

\section{Keasaman}

Mengacu pada BSN (2013), uji keasaman madu dilakukan secara titrasi asam basa menggunakan $0,1 \mathrm{~N}$ $\mathrm{NaOH}$. Nilai keasaman madu ditunjukkan oleh volume $0,1 \mathrm{~N} \mathrm{NaOH}$ yang ekivalen dengan asam dalam $1 \mathrm{Kg}$ madu sesuai dengan rumus (1) berikut.

$\mathrm{mL} 0,1 \mathrm{~N} \mathrm{NaOH} / \mathrm{Kg}$ madu $=\frac{\mathrm{a} \times \mathrm{b}}{\mathrm{c}} \times 1000 \ldots .(1)$

Keterangan :

$\mathrm{a}=$ volume $(\mathrm{mL}) \quad 0,1 \mathrm{~N} \mathrm{NaOH}$

$\mathrm{b}=$ normalitas $\mathrm{NaOH} 0,1 \mathrm{~N}$.

$\mathrm{c}=$ bobot (gram) sampel madu.

Uji aktivitas enzim diastase (BSN, 2013) Larutan induk iodum $0,03 \mathrm{M}$

Larutan ini dibuat dari $440 \mathrm{mg}$ iodum, ditambah dengan 1,1 gram KI dan air suling $2 \mathrm{~mL}$. Selanjutnya dimasukkan ke dalam labu ukur $50 \mathrm{~mL}$ dan ditambah air suling sampai garis tanda.

\section{Larutan iodum 0,0007 N}

Larutan ini dibuat dari 2,0 gram KI dan $0,5 \mathrm{~mL}$ larutan induk iodum $0,03 \mathrm{M}$ dan pelarut air suling dalam labu ukur $50 \mathrm{~mL}$.

\section{Larutan iodum encer}

Larutan ini dibuat dari $10,0 \mathrm{~mL}$ larutan iodum $0,0007 \mathrm{~N}$ ditambah dengan $20,0 \mathrm{~mL}$ air suling dan dikocok sampai homogen.

\section{Larutan dapar asetat pH 5,3 (1,59 M)}

Larutan ini dibuat dengan melarutkan 4,35 gram natrium asetat dalam $25 \mathrm{~mL}$ air suling. Kemudian ditambahkan $0,5 \mathrm{~mL}$ asam asetat, selanjutnya dikocok sampai homogen dan diperiksa keasamannya dengan pH-meter. Jika pH larutan belum mencapai 5,3 ditambahkan asam asetat sampai pH mencapai 5,3.

\section{Larutan natrium klorida $0,5 \mathrm{M}$}

Larutan ini dibuat dengan melarutkan 0,73 gram natrium klorida dalam air suling di dalam labu ukur $25 \mathrm{~mL}$. Larutan ini perlu sering diperbaharui karena mudah berjamur.

\section{Larutan pati}

Larutan ini dibuat dengan memanaskan sampai mendidih campuran $0,5 \mathrm{~g}$ amylum soluble dan $22 \mathrm{~mL}$ air suling dalam labu erlenmeyer $50 \mathrm{~mL}$. Setelah mendidih selama 3 menit, larutan didinginkan sampai suhu kamar, dipindahkan ke dalam labu ukur $25 \mathrm{~mL}$ dan ditambah air suling sampai garis tanda.

\section{Standardisasi iodine $\left(\mathbf{I}_{\mathbf{2}}\right)$}


Dipipet $5,0 \mathrm{~mL}$ larutan amilum soluble dimasukkan ke dalam erlenmeyer $50 \mathrm{~mL}$, kemudian ditambah $10,0 \mathrm{~mL}$ air suling dan dikocok sampai homogen. Campuran tersebut dipipet $1,0 \mathrm{~mL}$ dan dimasukkan ke dalam beberapa erlenmeyer $50 \mathrm{~mL}$ yang telah berisi $10,0 \mathrm{~mL}$ larutan iodum encer. Setelah ditambah dengan air suling (bervariasi) dan dikocok sampai homogen, diukur absorban larutan pada panjang gelombang $660 \mathrm{~nm}$ dengan spektrofotometer UV-Vis hingga diperoleh nilai absorban $0,760 \pm 0,02$.

\section{Persiapan sampel uji}

Ditimbang 5,0 gram madu, dimasukkan ke dalam beaker glass $50 \mathrm{~mL}$, ditambahkan $10-15 \mathrm{~mL}$ air suling dan 2,5 mL larutan dapar asetat, diaduk sampai madu larut seluruhnya. Kemudian larutan dipindahkan ke dalam labu ukur $25 \mathrm{~mL}$ yang telah berisi $1,5 \mathrm{~mL}$ larutan natrium klorida $0,5 \mathrm{M}$, kemudian ditambahkan air suling sampai garis tanda.

\section{Penetapan absorban sampel}

Dipipet 10,0 mL larutan sampel uji, dimasukkan ke dalam tabung reaksi, ditambahkan 5,0 mL larutan pati dan diletakkan dalam waterbath yang sudah diatur pada suhu $40^{\circ} \mathrm{C} \pm 0.2^{\circ} \mathrm{C}$ selama 15 menit, kemudian larutan dikocok dan stopwatch dihidupkan. Setiap interval waktu 5 menit, dipipet $1,0 \mathrm{~mL}$ campuran sampel tersebut dan ditambahkan ke dalam 10,0 mL larutan iodine yang sudah distandardisasi. Setelah dikocok sampai homogen kemudian diukur nilai absorbannya pada panjang gelombang $660 \mathrm{~nm}$. Dicatat waktu, sejak pencampuran pati dengan madu sampai penambahan larutan iodine, sebagai waktu reaksi. Pengambilan larutan dilanjutkan dalam selang waktu tertentu sampai diperoleh nilai $\mathrm{A}<0,235$. Dibuat kurva hubungan waktu pemanasan madu dengan absorban dari kompleks amilum-iodine. Dengan menggunakan persamaan regresi dari kurva hubungan tersebut dihitung harga DN dengan rumus (2) berikut.

$$
\mathrm{DN}=300 / t
$$

\section{Keterangan :}

$$
\begin{aligned}
\mathrm{DN}= & \text { Aktivitas enzim diastase } \\
t \quad= & \text { waktu yang digunakan untuk mencapai nilai } \\
& \text { absorban }(\mathrm{A}=0.235)
\end{aligned}
$$

Uji kadar HMF (BSN, 2013)

\section{Larutan Carrez I 0,35 M}

Larutan ini dibuat dengan melarutkan $1,5 \mathrm{~g}$ kalium ferosianida dalam air suling sampai $10 \mathrm{~mL}$.

\section{Larutan Carrez II 1,37 M}

Larutan ini dibuat dengan melarutkan 3,0 g zink asetat dalam air suling sampai $10 \mathrm{~mL}$.

\section{Natrium bisulfit $0,20 \%$}

Larutan ini dibuat dengan melarutkan $0,10 \mathrm{~g}$ natrium bisulfit dalam air suling sampai $50 \mathrm{~mL}$.

\section{Prosedur uji HMF}

Ditimbang seksama madu 5,0 g, dimasukkan ke dalam gelas piala $50 \mathrm{~mL}$ dan ditambah $25 \mathrm{~mL}$ air suling, diaduk sampai larut, kemudian larutan dipindahkan ke dalam labu ukur $50 \mathrm{~mL}$. Setelah ditambah 0,5 $\mathrm{mL}$ larutan Carrez I dan dikocok kemudian ditambahkan $0,5 \mathrm{~mL}$ larutan Carrez II, dikocok kembali dan diencerkan dengan air suling sampai garis tanda. Selanjutnya sampel disaring dengan kertas saring whatman nomor $42( \pm 10 \mathrm{~mL}$ saringan pertama dibuang), dipipet 5,0 $\mathrm{mL}$ hasil saringan dan masing-masing dimasukkan ke dalam dua tabung reaksi yang berbeda. Ke dalam tabung reaksi pertama dimasukkan 5,0 mL air suling (tabung sampel). Ke dalam tabung reaksi kedua dimasukkan 5,0 mL larutan 0,20\% natrium bisulfit (sebagai larutan pembanding). Kemudian diukur dan ditetapkan absorban sampel terhadap (pembanding) pada panjang gelombang $284 \mathrm{~nm}$ dan $336 \mathrm{~nm}$. Bila absorban lebih tinggi dari 0,6, larutan sampel diencerkan dengan air suling, sedangkan untuk larutan pembanding digunakan natrium bisulfit $0,10 \%$ (nilai absorban yang diperoleh dikalikan dengan faktor pengenceran sebelum saat perhitungan). Kadar HMF dihitung dengan rumus (3) berikut.

$\mathrm{HMF}(\mathrm{mg} / 100 \mathrm{~g}$ madu $)=\frac{(\mathrm{A} 284-\mathrm{A} 336) \times 14,97 \times 5}{\text { Bobot contoh }(\mathrm{g}) \quad \ldots .(3)}$

Faktor 14,97 adalah angka konversi berdasarkan bobot molekul HMF (126) dan absortivitas molar HMF pada panjang gelombang $284 \mathrm{~nm}$ (16830) serta pengenceran sampel dengan pelarut.

\section{Uji cemaran logam $\mathrm{Pb}, \mathrm{Cd}, \mathrm{Hg}$ dan $\mathrm{As}$}

Uji cemaran logam $\mathrm{Pb}, \mathrm{Cd}, \mathrm{Hg}$ dan As dilakukan sesuai SNI 01-2896-1998 (Cara uji cemaran logam dalam makanan) dan SNI 01-4866-1998 (Cara uji cemaran arsen dalam makanan).

\section{Uji batas kloramfenikol}

Uji kloramfenikol dilakukan sesuai prosedur tervalidasi dari laboratorium ULP menggunakan metode kromatografi lapis tipis menggunakan fase gerak $\mathrm{CHCl}_{3}$ : Etil Asetat (1:1). 


\section{Uji cemaran mikroba}

Uji cemaran mikroba dilakukan di laboratorium ULP sesuai Feng dkk. (2002), meliputi penentuan angka lempeng total (ALT) dan angka paling mungkin (APM) koliform, kapang dan khamir.

Uji gula pereduksi dan uji kadar sukrosa

Uji gula pereduksi dan uji kadar sukrosa dilakukan dengan prosedur sesuai SNI 01-2892-1992 (BSN, 1992).

\section{HASIL DAN PEMBAHASAN}

\section{Uji organoleptik}

Hasil uji organoleptik menunjukkan bahwa semua sampel mempunyai bau dan rasa manis khas madu, sehingga berdasarkan SNI 01-3545-2013 (BSN, 2013) semua sampel memenuhi syarat organo-leptik madu.

\section{Uji kadar air}

Hasil uji kadar air sampel tercantum pada Tabel 1 . Berdasarkan BSN (2013), syarat kadar air dalam madu maksimal $22 \%(\mathrm{~b} / \mathrm{b})$. Kadar air sampel dengan kode TR adalah $24,51 \%$, sehingga dinyatakan tidak memenuhi persyaratan batas kadar air. Madu yang baik adalah madu yang mengandung kadar air sekitar 17 - 21\% (Sihombing, 1997). Bervariasinya kadar air dalam madu dapat disebabkan oleh beberapa hal, di antaranya kelembaban udara, jenis nektar, proses produksi dan penyimpanan (Suranto, 2007). Kadar air yang tinggi juga dapat disebabkan oleh penanganan panen yang terlalu dini, sebab sebagian besar sarang masih belum tertutup lilin.

Tabel 1. Hasil uji kadar air dari sampel madu

\begin{tabular}{|c|c|c|c|c|}
\hline No. & Kode sampel madu & Kadar air $(\%$ b/b) & Rerata $(\% \mathrm{~b} / \mathrm{b})$ & Syarat (maksimal 22\%) \\
\hline \multirow{3}{*}{1.} & & 12,29 & \multirow{3}{*}{12,12} & \multirow{3}{*}{ Memenuhi } \\
\hline & ML & 12,65 & & \\
\hline & & 11,43 & & \\
\hline \multirow{3}{*}{2.} & & 16,86 & \multirow{3}{*}{16,87} & \multirow{3}{*}{ Memenuhi } \\
\hline & MD & 16,89 & & \\
\hline & & 16,85 & & \\
\hline \multirow{3}{*}{3.} & & 18,56 & \multirow{3}{*}{18,65} & \multirow{3}{*}{ Memenuhi } \\
\hline & P-IRT & 18,64 & & \\
\hline & & 18,75 & & \\
\hline \multirow{3}{*}{4.} & \multirow{3}{*}{ TR } & 24,63 & \multirow{3}{*}{24,51} & \multirow{3}{*}{$\begin{array}{c}\text { Tidak } \\
\text { Memenuhi }\end{array}$} \\
\hline & & 24,57 & & \\
\hline & & 24,32 & & \\
\hline
\end{tabular}

Penyimpanan madu dalam refrigerator merupakan salah satu alternatif untuk mengurangi kecepatan penurunan kualitas madu, karena suhu yang rendah dapat menghambat fermentasi dan kristalisasi madu (Sutami, 2003).

\section{Uji kadar abu}

Hasil uji kadar abu menunjukkan sampel ML tidak memenuhi syarat (BSN, 2013) (Tabel 2), melebihi batas maksimal kadar abu yaitu $0,5 \%$ (b/b). Madu berwarna gelap umumnya memiliki kandungan abu yang lebih tinggi (Gomes dkk., 2010). Madu ML yang digunakan dalam penelitian ini berwarna gelap. Kadar abu yang tinggi akan mempengaruhi aroma dan rasa madu.

Tabel 2. Hasil uji kadar abu dari sampel madu

\begin{tabular}{|c|c|c|c|c|}
\hline No. & Kode sampel madu & Kadar abu (\% b/b) & Rerata $(\% \mathrm{~b} / \mathrm{b})$ & Syarat (maksimal 0,5\%) \\
\hline 1. & ML & $\begin{array}{l}0,61 \\
0,66 \\
0,72\end{array}$ & 0,66 & Tidak Memenuhi \\
\hline 2. & MD & $\begin{array}{l}0,41 \\
0,35 \\
0,38\end{array}$ & 0,38 & Memenuhi \\
\hline 3. & P-IRT & $\begin{array}{l}0,29 \\
0,32 \\
0,22\end{array}$ & 0,28 & Memenuhi \\
\hline 4. & TR & $\begin{array}{l}0,27 \\
0,37 \\
0,21\end{array}$ & 0,28 & Memenuhi \\
\hline
\end{tabular}




\section{Uji padatan tidak larut air}

Hasil uji padatan tak larut air tercantum dalam Tabel 3. Padatan tak larut air dapat meliputi serbuk sari dan kotoran partikel lain. Berdasarkan BSN (2013), syarat untuk padatan tidak larut air maksimal $0,5 \%$ (b/b). Tingginya kadar padatan yang tidak larut air dalam madu menunjukkan kondisi yang tidak higienis dan proses panen yang buruk. Padatan yang tidak larut air dalam madu digunakan sebagai kriteria kebersihan madu (Gobessa dkk., 2012). Semua sampel madu telah memenuhi kriteria kebersihan madu (Tabel 3).

Tabel 3. Hasil uji padatan tidak larut air

\begin{tabular}{|c|c|c|c|c|}
\hline No. & Kode Sampel madu & Padatan tidak larut air (\%) & Rerata (\%) & Syarat (maksimal 0,5\%) \\
\hline \multirow{3}{*}{1.} & \multirow{3}{*}{ ML } & 0,42 & \multirow{3}{*}{0,42} & \multirow{3}{*}{ Memenuhi } \\
\hline & & 0,41 & & \\
\hline & & 0,44 & & \\
\hline \multirow{3}{*}{2.} & \multirow{3}{*}{ MD } & 0,49 & \multirow{3}{*}{0,49} & \multirow{3}{*}{ Memenuhi } \\
\hline & & 0,47 & & \\
\hline & & 0,50 & & \\
\hline \multirow{3}{*}{3.} & \multirow{3}{*}{ P-IRT } & 0,51 & \multirow{3}{*}{0,51} & \multirow{3}{*}{ Memenuhi } \\
\hline & & 0,53 & & \\
\hline & & 0,50 & & \\
\hline \multirow{3}{*}{4.} & \multirow{3}{*}{ TR } & 0,53 & \multirow{3}{*}{0,52} & \multirow{3}{*}{ Memenuhi } \\
\hline & & 0,52 & & \\
\hline & & 0,50 & & \\
\hline
\end{tabular}

\section{Uji keasaman}

Hasil uji keasaman menunjukkan bahwa semua sampel madu memiliki $\mathrm{pH}$ dalam rentang normal yaitu antara 3,4 sampai 6,1 (Anonim, 2009). Persyaratan
BSN (2013), keasaman madu maksimal setara dengan $50 \mathrm{~mL} \mathrm{NaOH} \mathrm{0,1} \mathrm{N/Kg} \mathrm{madu.} \mathrm{Berdasarkan} \mathrm{data} \mathrm{pada}$ Tabel 4, semua sampel memenuhi presyaratan uji keasaman.

Tabel 4. Hasil uji keasaman sampel madu

\begin{tabular}{|c|c|c|c|c|}
\hline No. & $\begin{array}{c}\text { Kode } \\
\text { Sampel } \\
\text { madu }\end{array}$ & $\begin{array}{c}\mathrm{mL} \mathrm{NaOH} \\
0,1 \mathrm{~N} / \mathrm{Kg} \\
\text { madu }\end{array}$ & $\begin{array}{c}\text { Rerata } \\
\mathrm{mL} \mathrm{NaOH} 0,1 \\
\mathrm{~N} / \mathrm{Kg} \mathrm{madu}\end{array}$ & $\mathrm{pH}$ \\
\hline 1. & ML & $\begin{array}{l}14,29 \\
14,75 \\
13,10 \\
\end{array}$ & 14,04 & $4,70-4,77$ \\
\hline 2. & MD & $\begin{array}{l}12,90 \\
11,76 \\
12,80 \\
\end{array}$ & 12,49 & $4,69-4,75$ \\
\hline 3. & P-IRT & $\begin{array}{l}8,16 \\
7,90 \\
8,05\end{array}$ & 8,04 & $4,26-4,29$ \\
\hline 4. & TR & $\begin{array}{l}8,26 \\
7,33 \\
7,43\end{array}$ & 7,67 & $5,50-5,56$ \\
\hline
\end{tabular}

Keasaman madu memberikan kontribusi terhadap rasa dan bertanggung jawab atas stabilitas yang sangat baik dari madu terhadap mikroorganisme. Keasaman madu meningkat karena penyimpanan yang lama atau terjadi fermentasi (White Jr dkk., 1980). 


\section{Aktivitas enzim diastase}

Hasil uji aktivitas enzim diastase tersaji pada Tabel 5. Berdasarkan BSN (2013), syarat aktivitas enzim diastase madu adalah minimal 3 DN. Sampel yang diuji memenuhi syarat yang ditentukan, yaitu semua menunjukkan DN lebih besar dari $3 \mathrm{DN}$.

Tabel 5. Hasil uji aktivitas enzim diatase

\begin{tabular}{ccccc}
\hline No. & $\begin{array}{c}\text { Kode } \\
\text { Sampel } \\
\text { madu }\end{array}$ & $\begin{array}{c}\text { Aktivitas } \\
\text { enzim } \\
\text { diastase } \\
(\mathrm{DN})\end{array}$ & $\begin{array}{c}\text { Rerata } \\
(\mathrm{DN})\end{array}$ & $\begin{array}{c}\text { Syarat } \\
\text { (minimal 3) }\end{array}$ \\
\hline \multirow{2}{*}{ 1. } & ML & $\begin{array}{c}11,12 \\
11,61\end{array}$ & 11,17 & Memenuhi \\
& & 10,78 & & \\
\hline & & 8,05 & & \\
2. & MD & 8,05 & 8,06 & Memenuhi \\
& & 8,09 & & \\
\hline & & 4,69 & & \\
3. & P-IRT & 4,75 & 4,83 & Memenuhi \\
& & 5,04 & & \\
\hline & & 10,89 & & \\
4. & TR & 10,84 & 10,85 & Memenuhi \\
& & 10,83 & & \\
\hline
\end{tabular}

Aktivitas enzim diastase dalam madu, ditentukan oleh pengolahan/pencampuran madu (Comesa Harmonised Standart, 2004). Aktivitas enzim diastase digunakan sebagai penanda untuk mengevaluasi kesegaran atau kerusakan madu. Pada pemalsuan madu yang dicampur dengan penambahan sukrosa atau High Fructose Corn Syrup (HFCS), terjadi pengurangan jumlah enzim diastase. Hal tersebut kadang dapat ditutupi oleh penambahan amilase asing, misalnya amilase roti cetakan (Voldrich dkk., 2009).

\section{Uji HMF}

Hasil uji HMF terhadap sampel madu tersaji pada Tabel 6. Sedangkan profil spektra HMF dalam sampel disajikan pada Gambar 1, 2, 3 dan 4.

Tabel 6. Hasil uji kadar HMF sampel madu

\begin{tabular}{|c|c|c|c|c|}
\hline No. & $\begin{array}{c}\text { Kode } \\
\text { Sampel } \\
\text { madu }\end{array}$ & $\begin{array}{c}\text { Nilai HMF } \\
(\mathrm{mg} / \mathrm{Kg} \\
\text { madu })\end{array}$ & $\begin{array}{c}\text { Rerata } \\
\text { Nilai } \\
\text { HMF }\end{array}$ & $\begin{array}{c}\text { Syarat } \\
(\text { maksimal 50) }\end{array}$ \\
\hline 1. & ML & $\begin{array}{l}91,94 \\
91,11 \\
91,91 \\
\end{array}$ & 91,65 & $\begin{array}{c}\text { Tidak } \\
\text { Memenuhi }\end{array}$ \\
\hline 2. & MD & $\begin{array}{l}290,85 \\
312,92 \\
261,32 \\
\end{array}$ & 288,37 & $\begin{array}{c}\text { Tidak } \\
\text { Memenuhi }\end{array}$ \\
\hline 3. & P-IRT & $\begin{array}{l}166,02 \\
191,45 \\
162,71 \\
\end{array}$ & 173,39 & $\begin{array}{c}\text { Tidak } \\
\text { Memenuhi }\end{array}$ \\
\hline 4. & TR & $\begin{array}{l}15,60 \\
19,70 \\
18,88\end{array}$ & 18,06 & Memenuhi \\
\hline
\end{tabular}

Keterangan: Berdasarkan BSN (2013), syarat

maksimal kadar HMF madu $50 \mathrm{mg} / \mathrm{Kg}$. 




Gambar 1. Spektra sampel madu ML

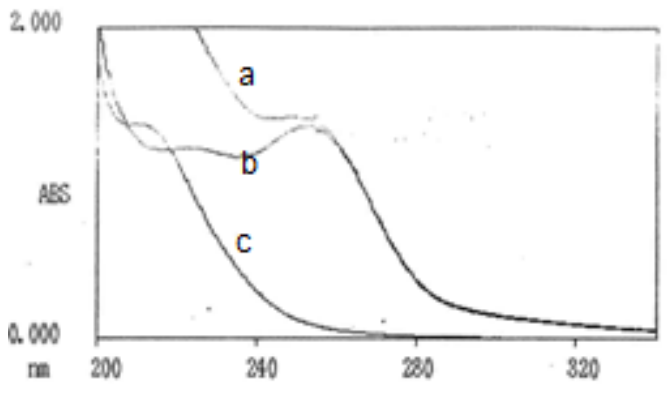

Gambar 3. Spektra sampel madu TR

Keterangan Gambar 1, 2, 3, 4:

a : sampel madu + air suling

b : sampel madu + natrium bisulfit $0,1 \%$

c : natrium bisulfit $0,1 \%$

Sampel madu TR berdasarkan perhitungan memenuhi syarat, tetapi data profil spektra (Gambar 3) tidak identik dengan spektra HMF menurut pustaka (Keppy \& Allen, 2009). Spektra HMF dalam sampel ML, MD dan P-IRT yang diperoleh setelah sampel diencerkan beberapa kali, identik dengan pustaka. Oleh karena itu, uji kadar HMF dalam sampel madu perlu dilakukan dengan metode lain yang lebih spesifik, misalnya kromatografi cair kinerja tinggi. Hal ini perlu dilakukan karena dalam produk madu tersebut diduga mengandung zat lain yang dapat mempengaruhi absorban HMF, khususnya pada $\lambda 284 \mathrm{~nm}$. Kadar HMF sampel madu ML, MD, P-IRT tidak memenuhi persyaratan karena lebih dari $50 \mathrm{mg} / \mathrm{Kg}$ madu. Menurut Zappala dkk. (2005), HMF tidak terdapat dalam madu segar dan cenderung meningkat secara alami selama pengolahan dan atau penuaan produk. Beberapa faktor mempengaruhi tingginya kadar HMF antara lain suhu, waktu pemanasan, kondisi penyimpanan, $\mathrm{pH}$ dan tanaman/bunga sumber asal madu (Gomes dkk., 2010). Kadar awal HMF yang tinggi memacu peningkatan kadar HMF selama penyimpanan. Penyimpanan selama 1 tahun pada suhu sejuk $\left(12-14^{\circ} \mathrm{C}\right)$ kadar HMF tidak meningkat secara bermakna (Dinkov, 2001)

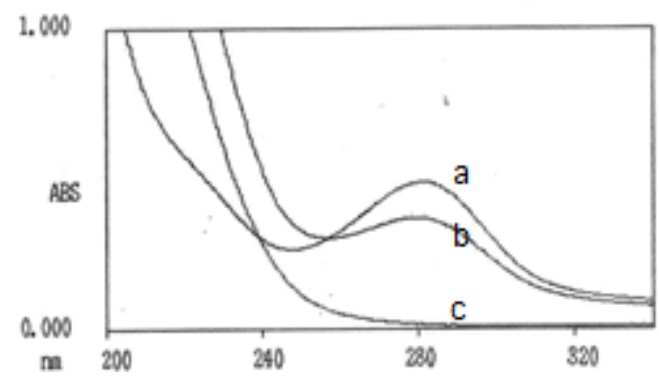

Gambar 2. Spektra sampel madu MD

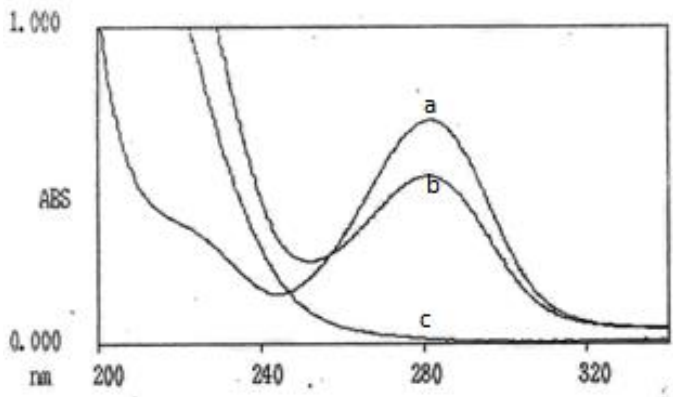

Gambar 4. Spektra sampel madu P-IRT

\section{Uji cemaran logam (Pb, Cd, Hg, As)}

Hasil uji cemaran $\mathrm{Pb}, \mathrm{Cd}, \mathrm{Hg}$ dan As memenuhi syarat (BSN, 2013), yaitu kadar $\mathrm{Pb}$ maksimal 2,0 mg/Kg, kadar Cd maksimal 0,2 mg/Kg, kadar $\mathrm{Hg}$ maksimal $0,03 \mathrm{mg} / \mathrm{Kg}$ dan kadar As maksimal $1,0 \mathrm{mg} / \mathrm{Kg}$.

\section{Uji kloramfenikol}

Hasil uji kloramfenikol dinyatakan memenuhi syarat (BSN, 2013), yaitu tidak terdeteksi adanya kloramfenikol dalam semua sampel madu.

\section{Uji cemaran mikroba}

\section{Angka lempeng total (ALT)}

Hasil uji Angka Lempeng Total (ALT) menunjukan bahwa semua sampel madu memenuhi syarat (BSN, 2013), yaitu ALT $<5 \times 10^{3} \mathrm{CFU} / \mathrm{mL}$

\section{Angka paling mungkin (APM) koliform}

Hasil uji APM koliform menunjukan bahwa semua sampel madu memenuhi syarat (BSN, 2013), yaitu APM koliform $<3$.

\section{Kapang dan khamir}

Hasil uji kapang dan khamir menunjukan bahwa sampel madu memenuhi syarat (BSN, 2013), yaitu kapang dan khamir $<1 \times 10^{1}$ koloni. 


\section{Uji gula pereduksi}

Hasil uji gula pereduksi (Tabel 7) menunjukan bahwa semua sampel madu memenuhi syarat (BSN, 2013), yaitu minimal mengandung gula pereduksi $65 \%$ (b/b). Gula pereduksi dalam madu dapat berupa glukosa, fruktosa, maltosa dan dekstrin. Sementara itu proses produksi madu oleh lebah sendiri merupakan proses yang kompleks, sehingga kemungkinan besar terjadi perbedaan kadar dan komposisi gula pereduksi di antara berbagai jenis madu yang beredar di masyarakat.

\section{Uji kadar sukrosa}

Hasil uji kadar sukrosa (Tabel 8) menunjukan semua sampel madu memenuhi syarat (BSN, 2013), yaitu mengandung maksimal $5 \% \mathrm{~b} / \mathrm{b}$.

Tabel 7. Hasil uji kadar gula pereduksi

\begin{tabular}{|c|c|c|c|c|}
\hline No. & $\begin{array}{c}\text { Kode } \\
\text { Sampel } \\
\text { madu }\end{array}$ & $\begin{array}{c}\text { Bobot } \\
\text { sampel } \\
\text { (mg) }\end{array}$ & $\begin{array}{c}\text { Kadar } \\
\text { glukosa } \% \\
\text { (b/b) }\end{array}$ & $\begin{array}{c}\text { Syarat } \\
\text { (minimal } \\
65 \%)\end{array}$ \\
\hline 1. & ML & $\begin{array}{l}5036,9 \\
5043,1\end{array}$ & $\begin{array}{l}78,94 \\
79,95\end{array}$ & Memenuhi \\
\hline 2. & MD & $\begin{array}{l}5051,0 \\
5053,6\end{array}$ & $\begin{array}{l}78,16 \\
77,51\end{array}$ & Memenuhi \\
\hline 3. & P-IRT & $\begin{array}{l}5055,3 \\
5052,0\end{array}$ & $\begin{array}{l}76,66 \\
77,54\end{array}$ & Memenuhi \\
\hline 4. & TR & $\begin{array}{l}5050,2 \\
5051,4\end{array}$ & $\begin{array}{l}65,02 \\
66,40\end{array}$ & Memenuhi \\
\hline
\end{tabular}

Tabel 8. Kadar sukrosa dalam madu

\begin{tabular}{ccccc}
\hline No. & $\begin{array}{c}\text { Kode } \\
\text { Sampel } \\
\text { madu }\end{array}$ & $\begin{array}{c}\text { Bobot } \\
\text { sampel }(\mathrm{mg})\end{array}$ & $\begin{array}{c}\text { Kadar } \\
\text { glukosa } \% \\
(\mathrm{~b} / \mathrm{b})\end{array}$ & $\begin{array}{c}\text { Syarat } \\
(\text { maksimal } \\
5 \%)\end{array}$ \\
\hline 1. & ML & $\begin{array}{c}5141,0 \\
5034,0\end{array}$ & 3,3 & Memenuhi \\
\hline 2. & MD & $\begin{array}{l}5135,0 \\
5154,0\end{array}$ & 4,8 & Memenuhi \\
\hline 3. & P-IRT & $\begin{array}{l}5111,0 \\
5154,0\end{array}$ & 1,7 & Memenuhi \\
\hline 4. & TR & $\begin{array}{l}5148,3 \\
5155,0\end{array}$ & 4,9 & Memenuhi \\
\hline
\end{tabular}

Sewaktu nektar dikumpulkan oleh lebah pekerja dari bunga, kadar air dalam madu masih tinggi (80\%), demikian juga sukrosa. Setelah lebah mengubah nektar menjadi madu, kandungan air menjadi rendah dan sukrosa diubah menjadi fruktosa dan glukosa (Sihombing, 1997). Resume hasil uji mutu sampel madu ditampilkan pada Tabel 9. 
Tabel 9. Resume hasil uji mutu madu

\begin{tabular}{|c|c|c|c|c|c|c|c|c|c|c|c|c|c|}
\hline \multirow[b]{2}{*}{ Sampel } & \multicolumn{13}{|c|}{ Parameter uji } \\
\hline & & 2 & 3 & 4 & $\begin{array}{l}5 \\
*\end{array}$ & $\begin{array}{l}6 \\
*\end{array}$ & 7 & 8 & 9 & 10 & 11 & 12 & $\begin{array}{l}13 \\
*\end{array}$ \\
\hline ML & $\sqrt{ }$ & $\sqrt{ }$ & $\mathbf{X}$ & $\sqrt{ }$ & $\sqrt{ }$ & $\sqrt{ }$ & $\sqrt{ }$ & $\sqrt{ }$ & $\mathbf{X}$ & $\sqrt{ }$ & $\sqrt{ }$ & $\sqrt{ }$ & $\sqrt{ }$ \\
\hline MD & $\sqrt{ }$ & $\sqrt{ }$ & $\mathbf{X}$ & $\sqrt{ }$ & $\sqrt{ }$ & $\sqrt{ }$ & $\sqrt{ }$ & $\sqrt{ }$ & $\sqrt{ }$ & $\sqrt{ }$ & $\sqrt{ }$ & $\sqrt{ }$ & $\sqrt{ }$ \\
\hline $\begin{array}{l}\text { P- } \\
\text { IRT }\end{array}$ & $\sqrt{ }$ & $\sqrt{ }$ & $\mathbf{X}$ & $\sqrt{ }$ & $\sqrt{ }$ & $\sqrt{ }$ & $\sqrt{ }$ & $\sqrt{ }$ & $\sqrt{ }$ & $\sqrt{ }$ & $\sqrt{ }$ & $\sqrt{ }$ & $\sqrt{ }$ \\
\hline TR & $\sqrt{ }$ & $\sqrt{ }$ & $\sqrt{ }$ & $\mathbf{X}$ & $\sqrt{ }$ & $\sqrt{ }$ & $\sqrt{ }$ & $\sqrt{ }$ & $\sqrt{ }$ & $\sqrt{ }$ & $\sqrt{ }$ & $\sqrt{ }$ & $\sqrt{ }$ \\
\hline
\end{tabular}

Keterangan Tabel 9:

$$
\begin{array}{ll}
\sqrt{ } & =\text { memenuhi syarat } \\
\mathrm{x} & =\text { tidak memenuhi syarat } \\
1 & =\text { Organoleptis } \\
2 & =\text { Aktivitas enzim diastase } \\
3 & =\mathrm{HMF} \\
4 & =\text { Kadar Air } \\
5 & =\text { Kadar gula pereduksi } \\
6 & =\text { Kadar sukrosa }
\end{array}
$$

\section{KESIMPULAN}

Berdasarkan hasil uji mutu madu dengan prosedur (BSN, 2013), dapat disimpulkan sebagai berikut: madu MD.137611002072 memenuhi syarat uji mutu madu kecuali uji HMF, madu ML.237608001190 memenuhi syarat uji mutu madu kecuali uji HMF dan uji kadar abu, madu P-IRT 109357813230 memenuhi syarat uji mutu madu kecuali uji HMF, sedangkan madu TR.053650821 memenuhi syarat uji mutu madu kecuali uji kadar air.

Penyimpanan madu sebaiknya dilakukan pada suhu sejuk dengan kelembaban rendah (kering), agar dapat menghambat laju fermentasi, peningkatan HMF, peningkatan aktivitas enzim diastase dan faktor-faktor lain yang dapat memicu rusaknya madu sehingga kualitas madu terjaga dengan baik.

\section{DAFTAR PUSTAKA}

Anonim. (2009). A Reference Guide to Nature's Sweetener by National Honey Board. https://www.honey.com/files/general/refguide.p df. Accessed: 7 Desember 2014.

Badan Standarisasi Nasional Indonesia (BSN). (1992). SNI-01-2891-1992: Cara Uji Makanan dan Minuman. Jakarta: Badan Standarisasi Nasional Indonesia.

Badan Standarisasi Nasional Indonesia (BSN). (2013). SNI-01-3545-2013: Madu. Jakarta: Badan Standarisasi Nasional Indonesia.

BPOM RI. (2012). Peraturan Kepala BPOM RI Nomor Hk.03.1.23.04.12.2205 Tahun 2012 tentang
7 = Keasaman

8 = Padatan tidak larut Air

9 = Kadar abu

10 = Cemaran logam

$11=$ Cemaran arsen

12 = Kloramfenikol

13 = Cemaran mikroba

Pedoman Pemberian Sertifikat Produksi Pangan Industri Rumah Tangga. Jakarta: BPOM RI.

Comesa Harmonised Standart. (2004). Standard for Honey, Revised Codex Standard For Honey. Codex Stan 12-1981; 1-8.

Departemen Kesehatan RI (Depkes RI). (2012). Peraturan Menteri Kesehatan RI No. 007 Tahun 2012 tentang Registrasi Obat Tradisional. Jakarta: Depkes RI.

Dinkov, D. H. (2001). Experimental Detection of Honey Adulteration with Iso Sweet $77555 \mathrm{P}$ using a Modification of Winkler's Method. Apiacta; 4.

Feng, P., Weagant, S. D., Grant, M. A. \& Burkhardt, W. (2002). Bacteriological Analytical Manual, Enumeration of Escherichia coli and the Coliform Bacteria (Chapter 4). Silver Spring: U. S. Food and Drug Administration.

Gobessa, S., Seifu, E. \& Bezabih, A. (2012). Physicochemical Properties of Honey Produced In The Homesha District Of Western Ethiopia. Journal of Apicultural Science; 56; 33-40.

Gomes, S., Dias, L. G. Leandro, L., Moreira, Rodrigues, P. \& Estevinho, L. (2010). Physicochemical, Microbiological and Antimicrobial Properties of Commercial Honeys from Portugal. Braganca: Centro de Investigação de Montanha (CIMO).

Keppy, N. K. \& Allen, M. W. (2009). The Determination of HMF in Honey with an Evolution Array UV-Vis Spectrophoto-meter. Madison: Thermo Fisher Scientific. 
Sihombing, D. T. H. (1997). Ilmu Ternak Lebah Madu. Yogyakarta : Gajah Mada University Press.

Suranto, A. (2007). Terapi Madu. Jakarta: Penebar Plus.

Sutami, A. (2003). Pengaruh Waktu Penyimpanan dalam Refrigerator terhadap Komposisi Kimia Madu Asli dan Madu Palsu. Skripsi; Fakultas Peternakan IPB, Bogor.

TGA. (1998). Honey Scientific Report. Office of Complementary Medicines. https://www.tga.gov.au/sites/default/files/reporthoney-9812.pdf. Accessed: 16 Desember 2013.
Voldrich, M., Rajchl, A., Cizkova, H. \& Cuhra, P. (2009). Detection of Foreign Enzyme Addition into the Adulterated Honey. Czech Journal of Food Sciences; 27; S280-S282.

White Jr, J. W. \& Doner, L. W. (1980). Honey Composition and Properties. Phila-delphia: Eastern Regional Research Center.

White, W. (1992). Honey (In: Graham, M. O. the Hives and the Honey Bee). Hamilton: Dadant and Son.

Zappala, M., Fallico, B., Arena, E. \& Verzera, A. (2005). Methods for the Determination of HMF in Honey: a Comparison. Food Control; 16; 273-277. 